\title{
PEMANFAATAN TEKNOLOGI MODIFIKASI CUACA UNTUK PERKEBUNAN KELAPA SAWIT
}

\author{
Samba Wirahma, Tri Handoko Seto, Ibnu Athoillah
}

\section{Intisari}

Tanaman Kelapa Sawit (Elais sp) adalah sumber utama minyak nabati sesudah kelapa di Indonesia. Tanaman tersebut merupakan komoditi andalan ekonomi Indonesia karena selain merupakan penghasil devisa, kelapa sawit merupakan salah satu alternatif upaya peningkatan kesejahteraan masyarakat melalui pembukaan lapangan pekerjaan dan lapangan usaha. Distribusi tanaman kelapa sawit di Indonesia dapat dijumpai di setiap pulau seperti Sumatera, Kalimantan, Sulawesi dan Jawa. Pada tahun 2013, dari total luas perkebunan kelapa sawit sebesar 9,14 juta hektar, sekitar 65\% berada di pulau Sumatera, disusul Kalimantan (31\%), Sulawesi (3\%), kemudian Jawa dan Papua di bawah satu persen.

Tanaman kelapa sawit tergolong ke dalam tanaman xerophyte yang dapat beradaptasi dengan kondisi air yang kurang, walaupun demikian tanaman tetap akan mengalami gejala stres air pada saat musim kemarau yang berkepanjangan. Salah satu upaya untuk mengantisipasi musim kemarau panjang dan kebakaran lahan yaitu dengan melakukan Teknologi Modifikasi Cuaca (TMC). Penerapan TMC di Indonesia sudah dilakukan sejak tahun 1979 dengan berbagai tujuan, yaitu menambah curah hujan untuk mengatasi kekeringan, pengisian air waduk untuk irigasi dan PLTA; mengurangi curah hujan untuk mengatasi banjir; longsor; dan mengurangi kabut asap akibat kebakaran hutan dan lahan.

Simulasi proyeksi curah hujan dengan skenario pelaksanaan TMC 120 hari dilakukan di wilayah Riau, Kalimantan Tengah dan Sumatera Utara sebagai daerah dengan luas perkebunan sawit terbesar di Indonesia. Hasil dari simulasi tersebut adalah menghitung besarnya jumlah curah hujan tahunan yang dapat dihasilkan apabila dilakukan TMC 120 hari pada bulan April-Mei 2014 dan Agustus-September 2014 dengan asumsi tingkat pertambahan hujan ketika berada pada periode penyemaian awan sebesar 30\%. Berdasarkan hasil simulasi curah hujan dengan skenario pelaksanaan TMC 120 hari, untuk wilayah Riau akan didapatkan penambahan curah hujan sebesar 198 mm/tahun, wilayah Kalimantan Tengah sebesar 254 mm/tahun dan wilayah Sumatera Utara sebesar $233 \mathrm{~mm} /$ tahun.

Palm (Elais sp) is the main source of vegetable oil after coco in Indonesia. This plant is mainstay commodity of Indonesia because in addition to foreign exchange earner, palm oil is one alternative efforts to improve the welfare of society through the opening of employment and business field. Distribution of palm oil plantations in Indonesia can be found in every island like Sumatra, Kalimantan, Sulawesi and Java. In 2013, total area of palm oil plantations amounted to 9.14 million hectares, approximately 65\% were on the island of Sumatra, Kalimantan followed (31\%), Sulawesi (3\%), then Java and Papua under one percent.

Palm oil plants belonging to the plant xerophyte that can adapt to conditions that are less water, however the plant will continue to experience symptoms of water stress during the long dry season. One effort to anticipate the long dry season and forest fires by performing the Weather Modification Technology. Application of this technology in Indonesia have been carried out since 1979 with a variety of purposes, namely to rain enhancement to overcome drought, filling water reservoirs for irrigation and hydropower; reduce rainfall to overcome floods; landslides; and reduce smog from forest fires and land.

Simulation of rainfall projection with applying weather modification technology for 120 days in Riau, Central Kalimantan, and North Sumatra as the area with the largest palm oil plantations in Indonesia. Result of this simulation is to calculate the amount of annual rainfall if weather modification for 120 days applied in April-May 2014 and AugustSeptember 2014, assuming growth rate when cloud seeding period is $30 \%$. Based on this simulation resulted for Riau regoin will get additional rainfall $198 \mathrm{~mm} / \mathrm{year}$, Central Kalimantan Region $254 \mathrm{~mm} / \mathrm{year}$ and North Sumatra Region $233 \mathrm{~mm} / \mathrm{year}$

Kata Kunci : Kelapa sawit, El-nino, Teknologi Modifikasi Cuaca, Simulasi curah hujan 


\section{PENDAHULUAN}

Tanaman Kelapa Sawit (Elaeis sp) merupakan komoditi andalan ekonomi Indonesia karena selain merupakan penghasil devisa, kelapa sawit merupakan salah satu alternatif upaya peningkatan kesejahteraan masyarakat melalui pembukaan lapangan pekerjaan dan lapangan usaha.

Kelapa sawit membutuhkan syarat kondisi agroekologi yang baik untuk mencapai pertumbuhan dan perkembangan optimum. Kondisi agroekologi yang dibutuhkan seperti lama penyinaran, curah hujan, temperatur udara, jenis tanah dan tingkat kemasaman tanah.

Air mempunyai peranan penting terhadap organisme khususnya tanaman. Air berfungsi sebagai penyusun tanaman $(70-90 \%$ dari total struktur tanaman), pelarut dan media bagi proses biokimia dalam tubuh tanaman, selain itu air berfungsi sebagai media transport dari senyawa, sebagai bahan baku dalam proses fotosintesis, menjaga suhu tanaman dan sebagai penyangga sel, memberikan turgor pada sel yang penting dalam pembentukan dan pembesaran sel tanaman.

Tanaman kelapa sawit seperti halnya tanaman yang lain juga memerlukan air untuk proses pertumbuhannya, mulai dari fase pembibitan hingga berproduksi. Pada kondisi ketersediaan air yang cukup tanaman kelapa sawit dapat tumbuh dan berproduksi secara optimal, namun hal tersebut dapat terganggu jika tanaman berada pada kondisi tercekam atau ketersediaan air tidak mencukupi untuk menjalankan proses metabolismenya.

\section{TINJAUAN PUSTAKA \\ 2.1. Asal usul dan Penyebaran Kelapa Sawit}

Tanaman kelapa sawit adalah sumber utama minyak nabati sesudah kelapa di Indonesia. Tanaman ini dikenal di dunia barat setelah orang Portugis berlayar ke Afrika pada tahun 1466. Dalam perjalanan ke Guinea, penduduk setempat terlihat menggunakan kelapa sawit untuk memasak maupun untuk bahan kecantikan. Pada tahun 1970 untuk yang pertama kali dikapalkan sejumlah biji kelapa sawit ke Inggris dan memasuki daratan benua Eropa tahun 1844. Beberapa tahun kemudian Eropa mengimpor inti sawit.

Tahun 1848 tanaman kelapa sawit masuk ke Indonesia dan daerah-daerah lain di Asia sebagai tanaman hias. Ada 4 tanaman yang ditanam di Kebun Raya Bogor(Bogor Botanical Garden) dahulu bernama Buitenzorg, dua berasal dari Bourbon (Mauritius) dan dua lainnya berasal dari Hortus Botanicus, Amsterdam (Belanda). Pada tahun 1853 keempat tanaman tersebut telah berbuah dan bijinya disebarkan secara gratis.
Pada pengamatan tahun 1858, ternyata keempat tanaman tersebut tumbuh subur dan berbuah lebat. Walaupun berbeda waktu penanaman (asal Bourbon lebih dulu dua bulan), tanaman tersebut berbuah dalam waktu yang sama, mempunyai tipe yang sangat beragam, kemungkinan diperoleh dari sumber genetik yang sama (Rutgers, 1922).

Kira-kira 10 tahun kemudian diadakan uji coba penanaman kelapa sawit pertama di Indonesia yang dilakukan di karesidenan Banyumas 14 acre dan di karesidenan Palembang (Sumatera Selatan) 3 acre. Hasil uji coba tersebut menunjukkan bahwa tanaman kelapa sawit telah berbuah pada tahun keempat setelah ditanam dengan tinggi batang $1,5 \mathrm{~m}$, sedangkan di negeri asalnya baru berbuah pada tahun keenam atau ketujuh. Selanjutnya uji coba dilakukan di Muara Enim tahun 1869, Musi Ulu 1870 dan Biliton 1890 (Van Heurn, 1948) tetapi tidak begitu baik pertumbuhannya. Hal ini baru disadari kemudian, bahwa iklim daerah Palembang kurang sesuai untuk pertumbuhan kelapa sawit. Kemudian dicoba dikembangkan ke Sumatera Utara dan ternyata hasilnya sungguh baik. Keunggulan kelapa sawit Sumatera Utara sudah dikenal sejak sebelum perang dunia ke II dangan varietas Dura Deli (bahasa Inggris : Deli Dura) yakni tanaman kelapa sawit yang ditanam di tanah Deli (Medan dan sekitarnya).

Selama 40 - 50 tahun sesudah tanaman kelapa sawit masuk ke Indonesia hanya digunakan sebagai tanaman hias, barulah pada tahun 1911 di perkebunkan di Sumatera Utara. Pada awal tahun 80-an, tanaman kelapa sawit digelari sebagai komoditi primadona karena memberi keuntungan yang melimpah dan akhirnya perluasan areal dapat terealisasi dengan kemajuan yang pesat.

\subsection{Agronomi Tanaman Kelapa Sawit}

Kedudukan tanaman kelapa sawit dalam sistematika tumbuhan dapat diklasifikasikan sebagai berikut :

1) Divisi : Magnoliophyta

2) Kelas : Liliopsida

3) Ordo : Arecales

4) Famili : Arecaceae

5) Genus : Elaeis

6) Spesies : Elaeis guineensis Jacq

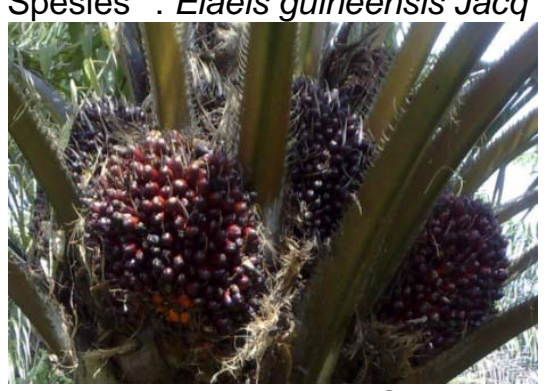

Gambar 1. Kelapa Sawit 


\subsection{Manfaat Produk Perkebunan Kelapa Sawit}

Ada tiga kegunaan utama dari produk perkebunan kelapa sawit yaitu untuk bahan pangan, kesehatan dan bahan baku energi. Kegunaan produk sawit untuk makanan dapat dijumpai sesudah CPO (Crude Palm Oil) diproses di pabrik pengolahan (refinery) CPO menjadi aneka produk seperti minyak goreng, margarine, pengganti lemak kakao (cacao butter substitute), minyak salad. Demikian juga untuk kesehatan, produk sawit dapat menghasilkan sabun, dan beragam produk turunan lemak sawit menjadi fatty alkohol, dan lain-lain. Kegunaan produk perkebunan kelapa sawit untuk bahan baku energi dapat diperoleh dengan mendayagunakan semua produk yang tidak digunakan untuk makanan dan kesehatan seperti pelepah, tempurung (cangkang sawit), sabut, batang pohon, tandan kosong dan limbah cairnya (POME-Palm Oil Mill Effluent).

\subsection{Distribusi, Luas Lahan, Produksi dan Produktivitas Kelapa Sawit di Indonesia}

Distribusi tanaman kelapa sawit di Indonesia dapat dijumpai di setiap pulau seperti Sumatera, Kalimantan, Sulawesi dan Jawa. Pada tahun 2013, dari total luas perkebunan kelapa sawit sebesar 9,14 juta hektar, sekitar 65\% berada di pulau Sumatera, disusul Kalimantan (31\%), Sulawesi (3\%), kemudian Jawa dan Papua di bawah satu persen.

Tabel 1. Perkembangan Perkebunan Kelapa Sawit di Setiap Pulau di Indonesia Tahun 2009 - 2013

\begin{tabular}{|l|c|c|c|c|c|}
\hline \multicolumn{1}{|c|}{ Nama Pulau } & $\mathbf{2 0 0 9}$ & $\mathbf{2 0 1 0}$ & $\mathbf{2 0 1 1}$ & $\mathbf{2 0 1 2}$ & $\mathbf{2 0 1 3}$ \\
\hline Sumatera & $5,221,824$ & $5,641,367$ & $5,867,176$ & $5,913,585$ & $5,956,955$ \\
\hline Kalimantan & $2,355,530$ & $2,462,207$ & $2,782,929$ & $2,814,782$ & $2,843,765$ \\
\hline Jawa & 27,163 & 28,057 & 25,687 & 26,112 & 26,445 \\
\hline Sulawesi & 211,380 & 196,302 & 257,955 & 260,588 & 262,799 \\
\hline Papua & 57,398 & 57,462 & 59,077 & 59,554 & 59,955 \\
\hline Luas Total (ha) & $\mathbf{7 , 8 7 3 , 2 9 5}$ & $\mathbf{8 , 3 8 5 , 3 9 5}$ & $\mathbf{8 , 9 9 2 , 8 2 4}$ & $\mathbf{9 , 0 7 4 , 6 2 1}$ & $\mathbf{9 , 1 4 9 , 9 1 9}$ \\
\hline
\end{tabular}

Sumber : Statistik Pertanian, Departemen Pertanian RI (2014)

Berdasarkan data perkembangan distribusi perkebunan kelapa sawit di setiap pulau yang disajikan pada Tabel 1, tampak bahwa pulau Sumatera telah mencapai puncak pertumbuhan, kemudian beralih ke Pulau kalimantan dan Sulawesi. Sementara itu untuk Pulau Jawa tidak mampu lagi dikembangkan untuk perkebunan sawit karena bersaing dengan kebutuhan lain dalam penggunaan lahan. Potensi lahan yang belum tergarap adalah Pulau Papua. Mungkin banyak pertimbangan teknis, sosial dan jarak yang jauh mengakibatkan pulau tersebut belum digarap secara optimum.

Perkebunan kelapa sawit menyebar di 22 Provinsi di empat pulau seperti Sumatera, Kalimantan, Sulawesi dan Papua.Berdasarkan data Departemen Pertanian RI (2014), Provinsi Riau menempati urutan tertinggi dalam luas perkebunan sawit, kemudian disusul Sumatera Utara dan Kalimantan Tengah. Tujuh provinsi yang tidak memiliki lahan perkebunan sawit adalah DKI Jakarta, Jawa Tengah, DI Yogyakarta, Jawa Timur, Bali, Nusa Tenggara Barat dan Nusa Tenggara Timur. (lihat gambar 2)

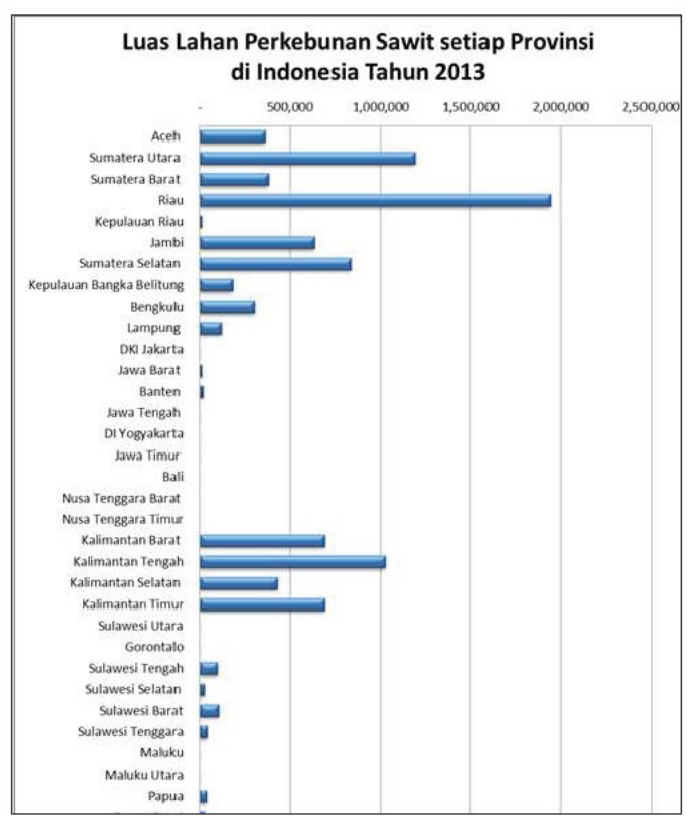

Gambar 2. Distribusi Luas Perkebunan Kelapa Sawit di Setiap Provinsi di Indonesia Tahun 2013 


\subsection{Karakteristik Agroekologi Kelapa Sawit}

Tanaman kelapa sawit tergolong ke dalam tanaman xerophyte yang dapat beradaptasi dengan kondisi air yang kurang, walaupun demikian tanaman tetap akan mengalami gejala stres air pada saat musim kemarau yang berkepanjangan (Mahamooth et al., 2008).

Suplai air untuk tanaman kelapa sawit dewasa di lapangan berasal dari curah hujan yang diterima dan ketersediaan air di tanah. Menurut Corley (2003), curah hujan merupakan salah satu dari beberapa syarat minimum iklim yang harus dipenuhi agar tanaman kelapa sawit dapat tumbuh dan berproduksi dengan baik. Adapun syarat-syarat tersebut adalah :

1. Panjang hari yang cukup dan radiasi sinar matahari $16-17 \mathrm{GJ} / \mathrm{m}^{2}$ per hari.

2. Curah hujan antara $2000-2500 \mathrm{~mm}$ yang terdistribusi secara merata.

3. Rendahnya defisit tekanan uap, tanpa adanya suhu dan kecepatan angin yang ekstrim.

4. Temperatur rata-rata maksimum $29-33^{\circ} \mathrm{C}$ dan minimum $22-24^{\circ} \mathrm{C}$.

Menurut Turner dan Gillbanks (2003), curah hujan tahunan $2000 \mathrm{~mm}$ yang terdistribusi merata sepanjang tahun tanpa adanya bulan kering berkepanjangan merupakan kondisi yang dibutuhkan untuk mencapai hasil yang maksimal. Untuk tanaman kelapa sawit dewasa ketersediaan air bersumber dari total curah hujan yang diterima, dimana kondisi curah hujan yang optimal adalah 2000-2500 mm/tahun.

\subsection{Penyebab Gagalnya Produksi Kelapa Sawit}

Selain terjadinya gangguan dari hama dan penyakit, penyebab gagalnya produksi kelapa sawit dapat disebabkan oleh keadaan alam yang sering menimbulkan kerugian pada perkebunan kelapa sawit, yaitu :

a. Kekeringan

Kekeringan dapat disebabkan oeh musim kemarau yang panjang sehingga terjadi kekurangan air di dalam tanah. Kekeringan dapat menghambat pertumbuhan dan produksi kelapa sawit. Musim kemarau panjang biasanya terjadi setiap $4-6$ tahun sekali. Akibat dari kekeringan panjang ini dapat berdampak hingga 2 - 3 tahun setelah musim kering berkepanjangan.

\section{b. Kebakaran}

Kebakaran merupakan salah satu akibat dari terjadinya kekeringan. Penyebab terjadinya kebakaran bisa disebabkan oleh kelalaian manusia (seperti membuang puntung rokok sembarangan) atau sebab lainnya. Jika terjadi kebakaran, kerugian menjadi sangat besar karena dapat mengakibatkan terhambatnya pertumbuhan tanaman dan membutuhkan waktu lama untuk pulih kembali.

\section{EL-NINO}

\subsection{Pengertian El-Nino}

El Nino adalah suatu gejala penyimpangan kondisi laut yang ditandai dengan meningkatnya suhu permukaan laut (sea surface temperatureSST) di samudra Pasifik sekitar equator (equatorial pacific) khususnya di bagian tengah dan timur (sekitar pantai Peru). Karena lautan dan atmosfer adalah dua sistem yang saling terhubung, maka penyimpangan kondisi laut ini menyebabkan terjadinya penyimpangan pada kondisi atmosfer yang pada akhirnya berakibat pada terjadinya penyimpangan iklim.

Dalam kondisi iklim normal, suhu permukaan laut di sekitar Indonesia (pasifik equator bagian barat) umumnya hangat dan karenanya proses penguapan mudah terjadi dan awan-awan hujan mudah terbentuk. Namun ketika fenomena el-nino terjadi, saat suhu permukaan laut di pasifik equator bagian tengah dan timur menghangat, justru perairan sekitar Indonesia umumnya mengalami penurunan suhu (menyimpang dari biasanya). Akibatnya, terjadi perubahan pada peredaran masa udara yang berdampak pada berkurangnya pembentukan awan-awan hujan di Indonesia.

\subsection{Dampak El-Nino}

Pusat prakiraan iklim Amerika (Climate Prediction Center) mencatat bahwa sejak tahun 1950, telah terjadi setidaknya 22 kali fenomena elnino, 6 kejadian di antaranya berlangsung dengan intensitas kuat yaitu 1957/1958, 1965/1966, 1972/1973, 1982/1983, 1987/1988 dan 1997/1998. Intensitas el-nino secara numerik ditentukan berdasarkan besarnya penyimpangan suhu permukaan laut di samudra pasifik equator bagian tengah. Jika menghangat lebih dari $1.5 \mathrm{oC}$, maka el-nino dikategorikan kuat.

Sebagian besar kejadian-kejadian el-nino itu, mulai berlangsung pada akhir musim hujan atau awal hingga pertengahan musim kemarau yaitu Bulan Mei, Juni dan Juli. El-nino tahun 1982/1983 dan tahun 1997/1998 adalah dua kejadian el-nino terhebat yang pernah terjadi di era modern dengan dampak yang dirasakan secara global. Disebut berdampak global karena pengaruhnya melanda banyak kawasan di dunia. Amerika dan Eropa misalnya, mengalami peningkatan curah hujan sehingga memicu bencana banjir besar, sedangkan Indonesia, India, Australia, Afrika mengalami pengurangan curah hujan yang menyebabkan kemarau panjang.

Di Indonesia, masih jelas dalam ingatan kita, pada tahun 1997 terjadi bencana kekeringan yang luas. Pada tahun itu, kasus kebakaran hutan di Indonesia menjadi perhatian internasional karena asapnya menyebar ke negara-negara tetangga. Kebakaran hutan yang melanda banyak kawasan di Pulau Sumatera dan Kalimantan saat 
itu, memang bukan disebabkan oleh fenomena elnino secara langsung. Namun kondisi udara kering dan sedikitnya curah hujan telah membuat api menjadi mudah berkobar dan merambat dan juga sulit dikendalikan. Di sisi lain, kekeringan dan kemarau panjang juga menyebabkan banyak wilayah sentra pertanian mengalami gagal panen karena distribusi curah hujan yang tidak memenuhi kebutuhan tanaman.

Publikasi-publikasi ilmiah menunjukkan bahwa dampak el-nino terhadap iklim di Indonesia akan terasa kuat jika terjadi bersamaan dengan musim kemarau, dan akan berkurang (atau bahkan tidak terasa) jika terjadi bersamaan dengan musim penghujan. Dampak el-nino juga ternyata berbeda-beda antara satu tempat dengan tempat lain, bergantung pada karakteristik iklim lokal. Oleh karena itu, menjadi menarik bagi para analis iklim untuk memperhatikan sebaran dampak el-nino dari bulan ke bulan (khususnya di musim kemarau) dan dari satu lokasi ke lokasi lain, berdasarkan catatan kejadian el-nino di masa lalu. Analisis semacam ini bisa dijadikan acuan dalam menyusun kebijakan terkait dampak elnino, misalnya saja dalam kebijakan tentang ketahanan pangan.

Tahun 2014, fenomena el-nino diperkirakan kembali terjadi. Rilis terbaru dari Earth Institute Columbia University, (salah satu rujukan dalam membuat prakiraan el-nino), menyebutkan bahwa peluang kejadian el-nino mencapai lebih dari 60 \%. El-nino tahun ini diperkirakan akan terjadi hingga awal tahun depan namun intensitasnya masih menjadi perdebatan. Sebagian memperkirakan el-nino lemah namun ada pula yang berpendapat akan terjadi el-nino sedang. Untuk mengantisipasi dampak el-nino, perlu kiranya kita mempelajari bagaimana perlaku iklim ketika dulu fenomena el-nino terjadi.

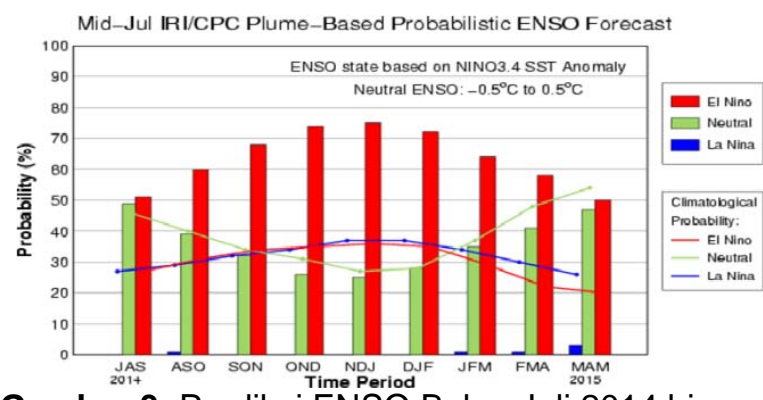

Gambar 3. Prediksi ENSO Bulan Juli 2014 hingga Maret 2015 dari Climate Prediction Center (CPC) \&International Research Institute (IRI)

Analisis terhadap kejadian-kejadian el-nino masa lalu dengan menggunakan data hujan global (produk dari Global Precipitation Climatology Center - GPCC) menunjukkan bahwa dampak el-nino juga dipengaruhi oleh intensitas (kuat-lemah) dan durasi berlangsungnya el-nino. Semakin kuat dan lama el-nino terjadi, semakin kuat dampaknya terhadap iklim di Indonesia khususnya curah hujan.

Pada kasus el-nino dengan intensitas lemah-sedang, untuk Bulan Juli - Agustus, el-nino akan berdampak pada pengurangan curah hujan dengan kisaran 40 - 80 \% (dibanding normalnya) terutama dirasakan di sebagian Sumatera, JatimBali-NTB-NTT, sebagian Kalimantan, Sulawesi, Maluku dan sebagian Papua. Sementara pada Bulan September - Oktober, dampak el-nino akan semakin parah ditandai dengan semakin luasnya area yang mengalami pengurangan curah hujan, meliputi seluruh Sumatera kecuali aceh, seluruh Jawa, Bali-NTB-NTT, sebagian besar Kalimantan, seluruh Sulawesi, Maluku dan sebagian besar Papua. Pada daerah NTB, NTT dan Sulawesi Tenggara bahkan curah hujan bisa berkurang hingga 20 - $40 \%$ dari normalnya

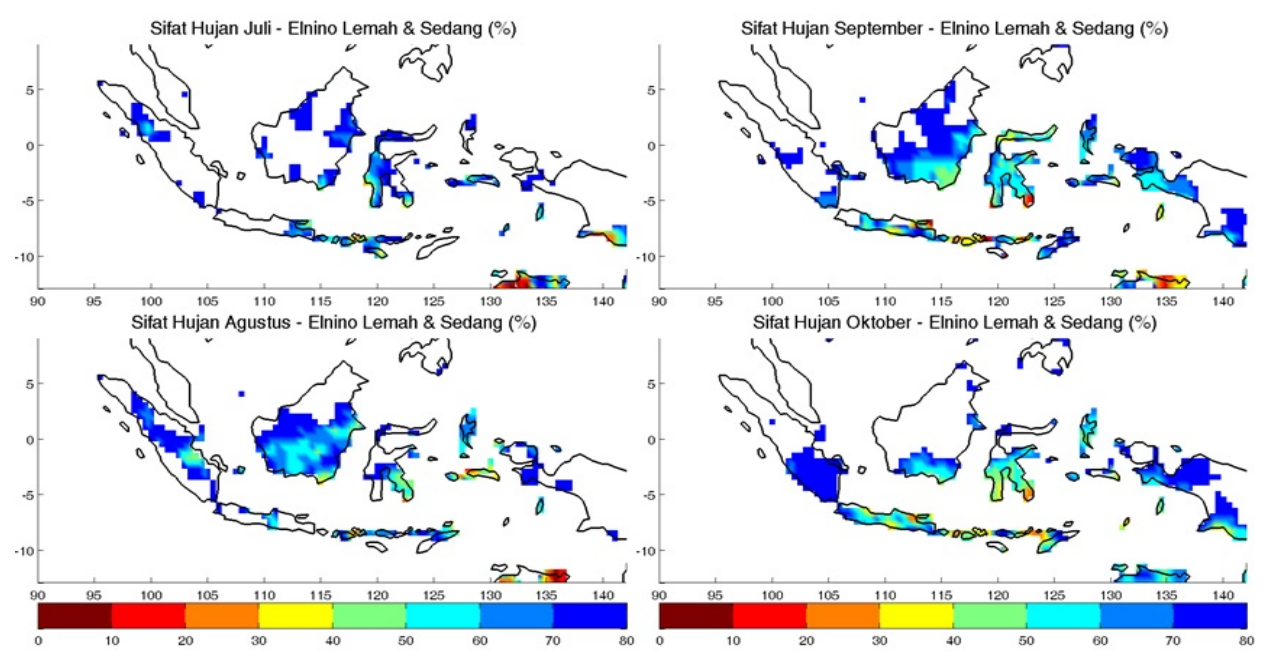

Gambar 4. Daerah Terdampak Jika Terjadi El-nino Lemah-Sedang, Dinyatakan Dalam Prosentasi Hujan Terhadap Normalnya

Solusi dalam menghadapi terjadinya kemarau panjang sulit dilaksanakan karena faktor 
iklim tidak dapat dikuasai oleh manusia. Salah satu upaya untuk mengantisipasi musim kemarau panjang yaitu dengan melakukan hujan buatan.

\section{Teknologi Modifikasi Cuaca \\ 4.1. Pemanfaatan Modifikasi Cuaca \\ Teknologi}

Salah satu upaya untuk mengantisipasi musim kemarau panjang dan kebakaran lahan yaitu dengan melakukan Teknologi Modifikasi Cuaca (TMC). TMC adalah suatu bentuk upaya intervensi manusia pada sistem awan untuk mengkondisikan cuaca agar berperilaku lebih mengarah sesuai dengan yang dibutuhkan, umumnya adalah untuk meningkatkan intensitas curah hujan atau mempercepat proses hujan di suatu tempat. TMC dilakukan dengan meniru proses alamiah yang terjadi di dalam awan. Sejumlah partikel higroskopik yang dibawa dengan pesawat sengaja ditambahkan langsung ke dalam awan jenis Cumulus (awan hujan) agar proses pengumpulan tetes air di dalam awan segera dimulai. Dengan berlangsungnya pembesaran tetes secara lebih efektif maka proses hujan menjadi lebih cepat dan menghasilkan curah hujan yang lebih banyak. Dalam hal ini, hujan yang terjadi diharapkan akan dapat mengisi embung-embung, pembasahan tanah dan bahkan hujan tersebut akan memadamkan sejumlah hotspot yang ada dan menipiskan kabut asap sehingga meningkatkan visibility (jarak pandang) yang kerap mengganggu kesehatan dan aktivitas penerbangan.

Penerapan TMC di Indonesia sudah dilakukan sejak tahun 1979 dengan berbagai tujuan, yaitu menambah curah hujan untuk mengatasi kekeringan, pengisian air waduk untuk irigasi dan PLTA; mangurangi curah hujan untuk mengatasi banjir; longsor; dan mengurangi kabut asap akibat kebakaran hutan dan lahan.

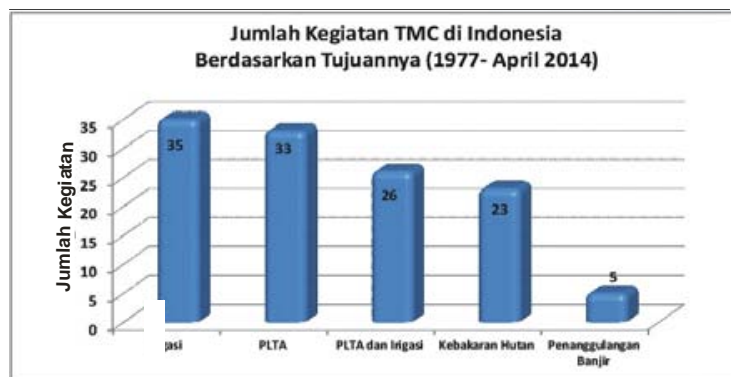

Gambar 5.Grafik Jumlah Pemanfaatan TMC di Indonesia Berdasarkan Tujuannya

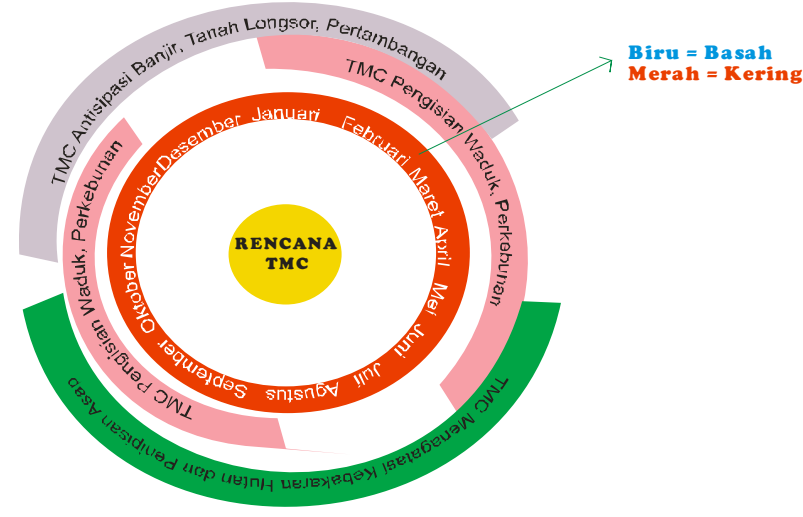

Gambar 6.Diagram Ruas-Waktu Pelaksanaan TMC di Indonesia Berdasarkan Kondisi Cuaca dan Pemanfaatan Pelayanannya.

Penerapan TMC di Indonesia sudah dilakukan sejak tahun 1979 dengan berbagai tujuan, yaitu menambah curah hujan untuk mengatasi kekeringan, pengisian air waduk untuk irigasi dan PLTA; mangurangi curah hujan untuk mengatasi banjir; longsor; dan mengurangi kabut asap akibat kebakaran hutan dan lahan.

\subsection{Evaluasi Hasil Kegiatan Teknologi Modifikasi Cuaca}

Tingkat keberhasilan TMC dapatditinjau dari hasil tambahan air hujan dari modifikasi cuaca. Maksud dari tambahan air hujan disini adalah peningkatan curah hujan pada periode pelaksanaan TMC. Sampai saat ini ada dua pendekatan besar dalam evaluasi yaitu dari segi curah hujan dan aliran. Metode evaluasi yang digunakan dalam analisa keberhasilan TMC baik itu dari segi curah hujan dan aliran adalah sebagai berikut :
1. Target Only
2. Target Kontrol
3. Analisis Double Ratio
4. Debit Aliran

Penggunaan metode-metode ini memerlukan data curah hujan historis dan curah hujan aktual pada daerah target (target area) dan daerah kontrol (kontrol area). Pendekatan yang digunakan adalah analisa statistik.

Dalam evaluasi TMC akan dihitung perbedaan antara curah hujan di daerah target pada periode penyemaian awan dengan curah hujan di daerah target seandainya tidak ada penyemaian. Nilai curah hujan di daerah target seandainya tidak ada penyemaian diperoleh dengan pendugaan. Pendugaan dilakukan dengan cara membandingkan curah hujan historis dengan curah hujan aktual pada saat dilakukan TMC atau dengan membandingkan curah hujan di daerah target pada periode penyemaian untuk desain target only. Untuk desain target kontrol pendugaan dilakukan dengan menggunaan persamaan regresi yang merupakan hubungan 
curah hujan antara daerah target dengan daerah kontrol.

Contoh salah satu perhitungan curah hujan menurut metode target only diberikan dalam persamaan berikut :

$$
\mathrm{R}=\left(\left(\mathrm{CH}_{\mathrm{a}}-\mathrm{CH}_{\mathrm{s}}\right) / \mathrm{CH}_{\mathrm{s}}\right) \times 100 \%
$$

dimana:

$\mathrm{R} \quad=$ Tingkat Pertambahan Hujan (\%)

$\mathrm{CH}_{\mathrm{a}}=$ Curah hujan wilayah aktual di daerah target $(\mathrm{mm})$

$\mathrm{CH}_{\mathrm{s}}=$ Rata-rata curah hujan wilayah historis di daerah target (mm)

Dari hasil-hasil kegiatan TMC yang sudah dilakukan, rata-rata tingkat pertambahan hujan ketika berada pada periode penyemaian awan yaitu sebesar 30\%.

\section{SIMULASI PROYEKSI CURAH HUJAN WILAYAH DENGAN SKENARIO PELAKSANAAN TMC 120 HARI}

Simulasi proyeksi curah hujan dengan skenario pelaksanaan TMC 120 hari dilakukan di wilayah Riau, Kalimantan Tengah dan Sumatera Utara sebagai daerah dengan luas perkebunan sawit terbesar di Indonesia. Simulasi dilakukan untuk kondisi curah hujan pada tahun 2014; dengan data curah hujan aktual hingga bulan Juli 2014; data curah hujan Agustus 2014 hingga Desember 2014 menggunakan perkiraan curah hujan jika terjadi el nino lemah-sedang; data curah hujan historis dari tahun 2001-2013; dan pelaksanaan TMC 120 hari dilakukan pada bulan April-Mei dan Agustus-September.

Hasil dari simulasi tersebut adalah menghitung besarnya jumlah curah hujan tahunan yang dapat dihasilkan apabiladilakukan TMC 120 hari pada bulan April-Mei dan Agustus-September 2014 dengan asumsi tingkat pertambahan hujan sebesar $30 \%$.

\subsection{Simulasi Curah Hujan Provinsi Riau}

Berdasarkan data sifat hujan pada kasus elnino dengan intensitas lemah sedang akan berdampak pengurangan curah hujan untuk daerah provinsi Riau. Untuk bulan Juli-Agustus curah hujan yang dihasilkan hanya berkisar 50 $80 \%$ dibanding normalnya, sementara untuk bulan September-Oktober curah hujan yang dihasilkan hanya berkisar $80 \%$ dibandingkan normalnya.

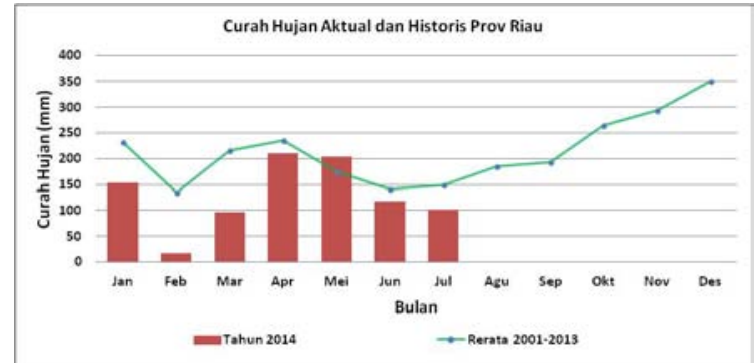

Gambar 7. Curah Hujan Aktual dan Historis Prov Riau.

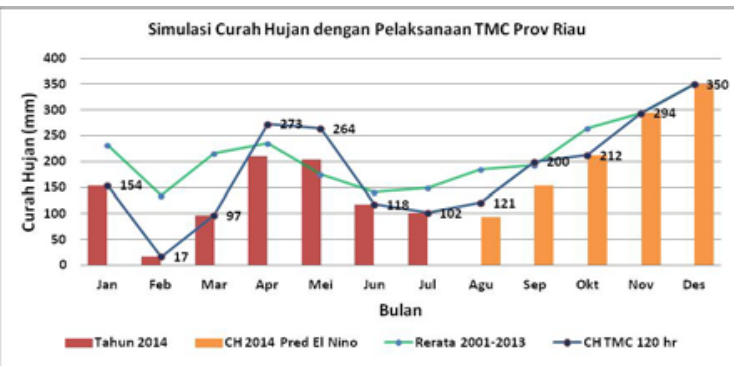

Gambar 8. Simulasi Curah Hujan Wilayah Riau Tahun 2014 dengan Skenario Pelaksanaan TMC 120 hari pada Bulan Apr-Mei \& Ags-Sep.

Berdasarkan hasil simulasi curah hujan wilayah Riau dengan skenario Pelaksanaan TMC 120 hari akan didapatkan penambahan curah hujan sebesar $198 \mathrm{~mm} /$ tahun.

\subsection{Simulasi Curah Hujan Provinsi Kalimantan Tengah}

Berdasarkan data sifat hujan pada kasus elnino dengan intensitas lemah sedang akan berdampak pengurangan curah hujan untuk daerah provinsi Kalimantan Tengah. Untuk bulan Juli-Agustus curah hujan yang dihasilkan hanya berkisar 50 - $80 \%$ dibanding normalnya, sementara untuk bulan September-Oktober curah hujan yang dihasilkan hanya berkisar 40 - $80 \%$ dibandingkan normalnya.

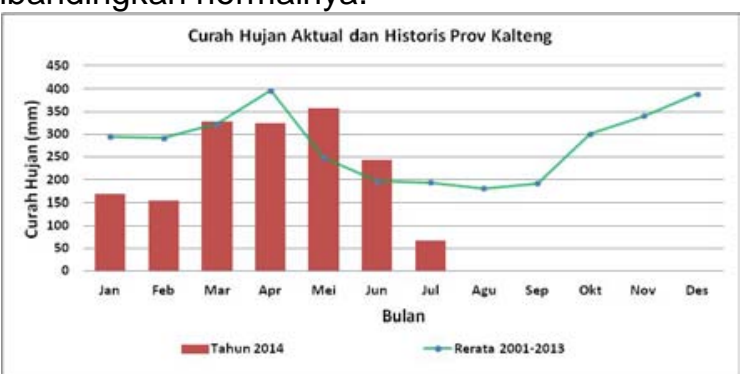

Gambar 9. Curah Hujan Aktual dan Historis Prov Kalimantan Tengah.

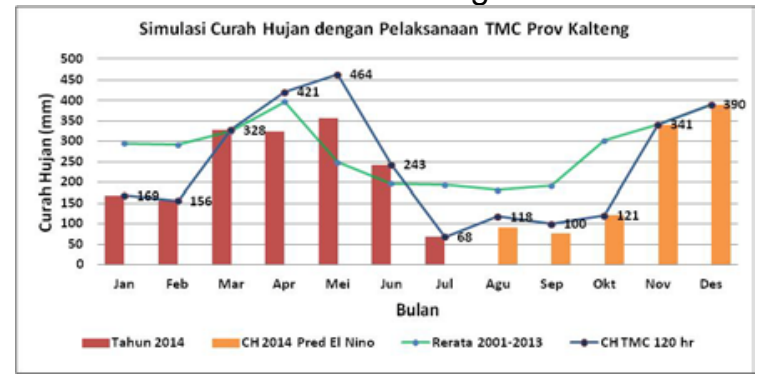


Gambar 10. Simulasi Curah Hujan Wilayah Kalimantan Tengah Tahun 2014 dengan Skenario Pelaksanaan TMC 120 hari pada Bulan Apr-Mei \& Ags-Sep.

Berdasarkan hasil simulasi curah hujan wilayah Kalimantan Tengah dengan skenario Pelaksanaan TMC 120 hari akan didapatkan penambahan curah hujan sebesar $254 \mathrm{~mm} / \mathrm{tahun}$.

\subsection{Simulasi Curah Hujan Provinsi Sumatera Utara}

Berdasarkan data sifat hujan pada kasus elnino dengan intensitas lemah sedang akan berdampak pengurangan curah hujan untuk daerah provinsi Sumatera Utara. Untuk bulan JuliAgustus curah hujan yang dihasilkan hanya berkisar 50 - $80 \%$ dibanding normalnya, sementara untuk bulan September-Oktober curah hujan yang dihasilkan hanya berkisar $80 \%$ dibandingkan normalnya.

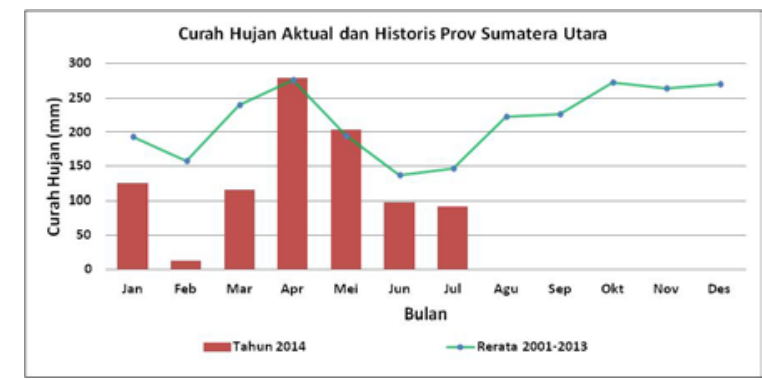

Gambar 11. Curah Hujan Aktual dan Historis Prov Sumatera Utara.

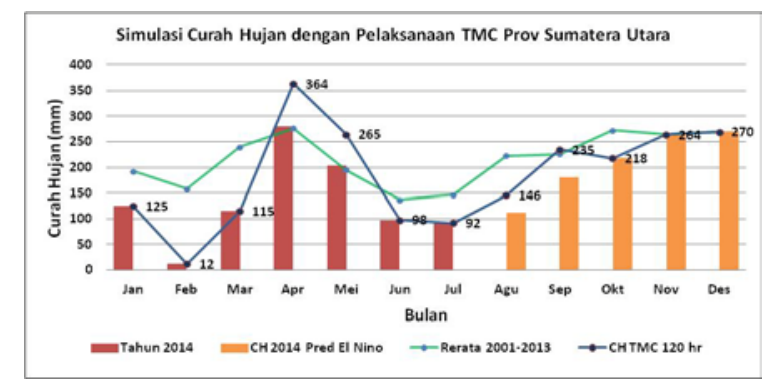

Gambar 12. Simulasi Curah Hujan Wilayah Sumatera Utara Tahun 2014 dengan Skenario Pelaksanaan TMC 120 hari pada Bulan Apr-Mei \& Ags-Sep.

Berdasarkan hasil simulasi curah hujan wilayah Sumatera Utara dengan skenario Pelaksanaan TMC 120 hari akan didapatkan penambahan curah hujan sebesar $233 \mathrm{~mm} / \mathrm{tahun}$.

\section{KESIMPULAN}

Distribusi tanaman kelapa sawit di Indonesia dapat dijumpai di setiap pulau seperti Sumatera, Kalimantan, Sulawesi dan Jawa. Pada tahun 2013, dari total luas perkebunan kelapa sawit sebesar 9,14 juta hektar, sekitar 65\% berada di pulau Sumatera, disusul Kalimantan
(31\%), Sulawesi (3\%), kemudian Jawa dan Papua di bawah satu persen.

Tanaman kelapa sawit tergolong ke dalam tanaman xerophyte yang dapat beradaptasi dengan kondisi air yang kurang, walaupun demikian tanaman tetap akan mengalami gejala stres air pada saat musim kemarau yang berkepanjangan. Salah satu upaya untuk mengantisipasi musim kemarau panjang dan kebakaran lahan yaitu dengan melakukan Teknologi Modifikasi Cuaca (TMC).

Simulasi proyeksi curah hujan dengan skenario pelaksanaan TMC 120 hari dilakukan di wilayah Riau, Kalimantan Tengah dan Sumatera Utara sebagai daerah dengan luas perkebunan sawit terbesar di Indonesia. Hasil dari simulasi tersebut adalah menghitung besarnya jumlah curah hujan tahunan yang dapat dihasilkan apabila dilakukan TMC 120 hari pada bulan AprilMei dan Agustus-September 2014 dengan asumsi tingkat pertambahan hujan sebesar $30 \%$.

Berdasarkan hasil simulasi curah hujan dengan skenario pelaksanaan TMC 120 hari, untuk wilayah Riau akan didapatkan penambahan curah hujan sebesar $198 \mathrm{~mm} / \mathrm{tahun}$, wilayah Kalimantan Tengah sebesar $254 \mathrm{~mm} /$ tahun dan wilayah Sumatera Utara sebesar $233 \mathrm{~mm} / \mathrm{tahun}$.

\section{DAFTAR PUSTAKA}

Badrun, M. 2010: Lintasan 30 tahun Pengembangan Kelapa Sawit. Direktur Jendral Perkebunan, Kementerian Pertanian RI.

Corley, R. H. V. and Tinker, P B. 2003.The Oil Palm Fourth Edition. Blacwell Science Ltd. United Kingdom.p56-64

Departemen Pertanian RI. 2014. Statistik Pertanian. Jakarta.

Gunarso, P, M. E. Hartoyo, Y. Nugroho, N.I. Ristiana, R. S. Maharani. 2012: Analisis Penutupan Lahan Dan Perubahannya Menjadi Kebun Kelapa Sawit di Indonesia Tahun 1990-2010.

Harahap, I. Y, Y Pangaribuan, H. H Siregar, E Listia. 2005.Lingkungan Fisik Perkebunan Kelapa Sawit. PPKS. Medan

Mahamooth, T. N., Gan, H.H., Kee, K.K., dan Goh, K.J. 2008.Water requirements and cycling of oil palm. Proceedings of Agronomy Crop Trust (ACT) Agronomic Principles and Practices of Oil palm Cultivation. Sarawak.p 57-96

Nur, M Syukri. 2014. Karakteristik Kelapa Sawit Sebagai Bahan Baku Bioenergi. PT Insan Fajar Mandiri Nusantara. Bogor.

Pahan, lyung. 2006. Panduan Lengkap Kelapa Sawit: Manajemen Agribisnis dari Hulu hingga Hilir. Swadaya. Jakarta. 
Supari. 2014. Sejarah Dampak Elnino di Indonesia. Artikel. http://www.bmkg.go.id

Tikno, S. 2010. Evaluasi Hasil Kegiatan Teknologi Modifikasi Cuaca di Indonesia. Artikel. http://www.wxmod.bppt.go.id

Turner, P. D. and Gillbanks, R. A. 2003. Oil palm cultivation and management second edition. The Incorporated Society Of Planters. Kuala Lumpur. p 74-81. 